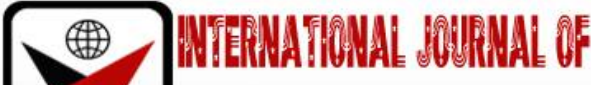

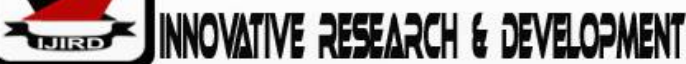

ISSN 2278 - 0211 (Online)

\section{The Effect of Money Supply on Economic Growth in Rwanda}

\author{
Jacques Ntezimana \\ Student, School of Business, Jomo Kenyatta University of Agriculture and Technology, Kenya \\ Dr. Patrick Mulyungi \\ Lecturer, School of Business, Jomo Kenyatta University of Agriculture and Technology, Kenya
}

\begin{abstract}
:
The purpose of this study was to assess the effect of money supply on economic growth in Rwanda. the study utilized quarterly time series data for the period of 2000-2015 and the variables considered are the ratios that were extracted and computed from data provided by the National Bank of Rwanda (BNR).The dependent variable was represented by economic growth which has as main indicator of real gross domestic product growth (real GDP), while the independent variable was represented by the broad money supply (M3) as a proportion of growth. In addition, five intervening variables were considered in order to control other components of the Rwanda macroeconomic environment that could influence the growth of the Rwanda economy. The study used Johnson co-integration technique to test the presence of long run between the study variables. Finally, the Fully Modified Ordinally Least Square (FMOLS) procedure was utilized to produce the model coefficients. From the empirical analysis, the result supported for a significant negative influence of money supply on the growth of economy (RGDP). This study therefore recommends Rwandan policy makers not utilize money supply to stimulate economic growth in both short and long relationship because of its inverse relationship with growth of economy.
\end{abstract}

Keywords: Money supply, economic growth, johnson co-integration

\section{Introduction}

Money supply is a fundamental macroeconomic component that influences the growth of economy in guaranteeing viable running of economic activities in both public and private segments through liquidity accessibility (Chude, 2016).Through money supply, the private sectors can get credits to carry on businesses at a value being alluded to as interest rate. Globally, monetary policy is an important instrument used by Central Banks of countries to maintain economic stability and promote economic growth(IMF,2017).However, monetarists believe that an increase in the money supply will not affect to output or gross domestic product (GDP), but money supply will affect mainly on inflation (Prasert Chaitip,2015).

For the AEC, in order to resolve the issues and stimulate economic growth, the government of AEC countries passed an alternative policy in every way. One of the measures of government spending based on monetary policy to stimulate the economy have been adopted, together with fiscal policy. The central bank's monetary policy to stimulate economic growth by lowering interest rates in order to increase the supply of money into the economy. Due to monetary policy plays as an important role in boosting the economic growth of many countries provided money as exogenously determined within the economy. So, changes in the quantitative money lead to change on aggregate demand sequence of AEC economic events of the number of sectors is still a very researchable subject, and for the third millennia there is the main arrangement modern(Prasert Chaitip,2015).

In Rwanda, monetization of the economy declined as the ratio of the money supply, M3, to GDP, fell from 23.9 percent at the end of 2016 to 23.6 percent at the end of 2017. Though depressed in the first half of 2017, growth of credit to the private sector began to respond to improved conditions and reached 13.2 percent by year end, up from less than 8 percent at midyear. Meanwhile, in 2017 credit available to the private sector held at about 19 percent of GDP (World Bank 2018). Despite the gradual monetary easing, monetary and credit conditions have stayed relatively tight.

Given the critical role money supply plays in pursuit of an economic growth, the study seeks to examine whether money supply influencing economic growth in Rwanda. We believe that the study findings would be valuable to policymakers who must prioritize among multiple policy reforms to help the economy grow faster. LITERATURE REVIEW There is huge literature generally on association between money supply and economic growth, these literatures follow many mechanisms of the arguments with varying and often contradicting views. A review of connected literature discovered that the results regarding the effect of money supply on economic growth are varied. 
Some studies supported for a negative effect, positive effect and other did not. These varied findings imply that there's nonetheless no agreement on the size and direction of relationship between money supply and growth of economy across worldwide.

The monetarists believe that money supply is a tool that gives boost to economic growth based on unexpected increase in money stock (Ali,2011) while the Keynesians argue that money supply has a limited influence on economic growth (Twinoburyo,2017).

Babatude and Shuaibu (2011) concentrated on money supply, inflation and economic growth. They found positive and huge relationship between money supply and economic growth in Nigeria for the period spreading over 1975 and 2008 utilizing utilized ARDL model.

Furthermore, Hameed et al (2011) studied the effect of monetary policy on gross domestic product for Pakistan and they found the growth in money supply greatly affects GDP. Some other scholars that found positive effect of impact of money supply on economic growth included Aslam (2011) in Sri Lanka among others. Same findings as Saša O. et al. (2015) in Serbia.

On other hand, few scholars found statistically significant and negative impact between money supply and economic growth. Gatawa (2016) tested impact of money supply in economic growth in Nigeria and has his results confirmed that money supply impact negatively on economic growth. Same as Abdulgafar and Olarinde (2017) inspected the connection between money supply and GDP in Nigeria and their discoveries showed that wide money supply and premium influence adversely on growth of the economy.

Another examination affirm on a similar outcome was the investigation of Ihsan and Anjum (2013) who assessed the effect of money supply on GDP in Pakistan, and they revaluated measurably unimportant and negative impact of cash supply on development of the country.

Some scholars like Adusei (2013) in Ghana on other hand, establish that financial sector development together with money supply undermines economic growth. This finding are like (Kamaan, 2014) who also found that money supply exerts in significant influence on economic growth there by substantiating the Keynesian view.

These contrasting views on the relationship between money supply and economic growth keep the policy in dilemma on controlling economic growth using money supply as proxies of financial sector development.

\section{Methodology}

This research used purely secondary data. It utilized quarterly time series data for the period of 2000-2015 and the variables considered time series are ratios that was extracted and computed from data provided by the National Bank of Rwanda (BNR).

The dependent variable is represented by economic growth which has as main indicator of real gross domestic product growth (real GDP), and is defined as the total added value of goods and services produced in a country during a specified time of period while the independent variable was represented by the broad money supply (M3) as a proportion of growth (RMS_gdp).

In addition, five intervening variables were included to capture other components of the Rwanda macroeconomic environment that could influence the growth of the Rwanda economy. These are the credit to private sector as a ratio of GDP (RCPS_gdp), the bank deposit liability as ratio of GDP (RBDL_gdp), the interest rate margin (IR), gross fixed capital formation (proxy for investment) as ratio of GDP (RGCF_gdp) and total trade (exports plus imports) to GDP (RTT_gdp).The model is written as follows

RGDP $=\beta 0+\beta 1$ RMS_gdp $+\beta 2$ RCPS_gdp $+\beta 3$ RBDL_gdp $-\beta 4$ IR $+\beta 5$ RGCF_gdp $+\beta 6$ RTT_gdp $+\varepsilon t$

The parameters to be estimated are $\beta 0$ (constant) and $\beta \mathrm{i}(\mathrm{i}=1,2 \ldots 6)$, which are the slope parameters, which are the slope parameters. $\varepsilon$ t is an error term that is identically and independently distributed with zero mean and constant variance $\sigma 2$.

All statistical estimations and analysis were carried out using E-Views and R econometric packages. The Augmented Dickey-Fuller (ADF) unit root test was applied to test the stationarity in variables in order to avoid the spurious regression problem. The Augmented Dickey-Fuller test was conducted on each variable based on the null hypothesis of stationarity and failure to reject the null implies the need for appropriate differencing to bring stationarity.

Further, if variables series are non-stationary, this indicates that they have unit root. Therefore, before making any kind of estimation, one must make a test for unit root for the time series. If the time series has unit root, what follows is the transformation of that non-stationary time series into one that is stationary. One way of inducing stationarity in nonstationary series $\mathrm{I}(\mathrm{d})$, is to be differenced of order $\mathrm{d}$ before getting to $\mathrm{I}(0)$ or simply to say the series becomes stationary. Once a unit root has been confirmed for a data series, the question is whether a long-run equilibrium relationship exists among variables. Having confirmed in this study that all variables included in the models were integrated of order one, the next step was to test independently for the existence of co-integration relationships between moneysupply and economic growth. For this purpose, the study used the Johansen co-integration test procedure. To account for possible long-run endogeneity in the included variables of equations (1), the parameters were estimated using the Fully Modified Ordinary Least Squares (FMOLS) method.

After discovering a suitable Johnson equation that best defines the data, the next step comprises assessing a conforming error correction model for the growth of economy. The VECM takes both the long-run equilibrium to which outcome come together over time and the rate of alteration resulting disequilibrium. This model is re written in the following form:

$6 \quad 6$

$\Delta \mathrm{Y}_{t}=\alpha_{0}+\Sigma \beta_{i} \Delta X_{t-i}+\Sigma \gamma j \Delta \mathrm{Y}_{t-j}+\rho \varepsilon_{t-1}+\mu_{t}(2)$ 
Where $\Delta$ means the 1 st difference, $\varepsilon$ t is the estimated residual from the nominated Johnson co-integration equation, RGDP is as defined as real gross domestic product whereas Xt is the vector of exogenous variables, namely RMS_gdp. For a stable model, the measurement? which processes the speed of adjustment of the outcome variable to the value implied by the long run equilibrium relationship, must be statistical significantly and negative direction.

\section{Results and Findings}

\subsection{Tests for Stationarity}

The empirical findings of augmented Dickey Fuller Unit Root Test done on the included variables are summarized in Table 1, Real GDP is integrated at order zeroI (0) while ration of money supply on RGDP (RMS_gdp) is integrated of order oneI (1). This implies that RMS_gdp become stationary after being differenced. Thus, the variables were entered the error correction model in their form differentiation to estimate the short run relationship. The stationarity is conformed when critical ADF is great than critical value.

\begin{tabular}{|c|c|c|c|c|c|c|c|}
\hline \multirow[b]{2}{*}{ Variables } & \multicolumn{2}{|c|}{ Level } & \multicolumn{2}{|c|}{$1^{\text {st }}$ difference } & \multicolumn{2}{|c|}{$2^{\text {nd }}$ difference } & \multirow[b]{2}{*}{ Decision 0 } \\
\hline & $\mathrm{ADF}^{\mathrm{c}}$ & ADFct & ADFc & ADFct & ADFc & ADFct & \\
\hline RGDP & 1.12 & -3.49 & & & & & $\mathrm{I}(0)$ \\
\hline RMS_gdp & 2.89 & -1.78 & -2.25 & -4.17 & & & $\mathrm{I}(1)$ \\
\hline RCPS_gdp & 4.59 & -0.92 & -4.97 & -7.15 & & & $\mathrm{I}(1)$ \\
\hline RBDL_gdp & 2.99 & -1.085 & -2.27 & 7.89 & & & $\mathrm{I}(1)$ \\
\hline IR & -2.06 & -2.73 & -8.13 & -8.06 & & & $\mathrm{I}(1)$ \\
\hline RGCF_gdp & -2.77 & -2.71 & -4.83 & -4.81 & & & $\mathrm{I}(1)$ \\
\hline RTT_gdp & -0.13 & -3.04 & -2.59 & -2.98 & -8.58 & -8.52 & $\mathrm{I}(2)$ \\
\hline
\end{tabular}

Table 1: Augmented Dickey Fuller Unit Root Test Results Adfc Represents Unit Root Test with Intercept Adfct Represents Unit Root Test with Intercept and Trend

*Mackinnon (1996) Critical Values with Intercept Are: -3.5576(1\%) -2.9166(5\%) and 2.5961(10\%)

*Mackinnon (1996) Critical Values with Intercept and Trend Are: -4.1373(1\%) -3.4953(5\%) and 3.1766(10\%)

\subsection{Estimation of Long Run Estimates}

The results in Table 2 show that the coefficient of RMS_gdp was found to be negative and significant at 5\%, this means that an increase in money supply (RMS_gdp), would lead to a subsequent reduction in growth in the Rwandan long run economy. This resultjoints the one found by Gatawa (2016), case of Nigeria among others. At 95\%, the R-squared gotten was satisfactorily high, suggesting that the model describes about $98 \%$ of the variation in growth. Other variables presented in this table were used as control variables.

\begin{tabular}{|c|c|c|}
\hline & Coefficient & Prob. \\
\hline RMS_gdp & -339.57 & 0.013 \\
\hline RCPS_gdp & 92.09 & 0.020 \\
\hline RBDL_gdp & 322.73 & 0.120 \\
\hline IR & 5.28 & 0.045 \\
\hline RGCF_gdp & -47.36 & 0.286 \\
\hline RTT_gdp & 19.11 & 0.076 \\
\hline C & 270.47 & 0.000 \\
\hline Trend & 19.33 & 0.000 \\
\hline R-squared (R2) & 0.89 & \\
\hline
\end{tabular}

\subsection{Short Run Relationship Estimates for Error Correction Model}

The results from Table 3presented the estimates of the ECM estimated based on the residuals gotten from Model presented in Table 2. These coefficients are the Fully Modified Ordinary Least Square (MOLS) coefficient of the error correction outcome model. At the level of significant of 5 per cent the ratio ofmoney supply hasfound to be the causes of growth in the short run.

The coefficient of the ECM was gotten to be statistically significant and negative at 0.5 per cent significant level, additional which revealed evidence of a short-run co-integrating relationship for the included variables. At -0.13 , the magnitude of the ECM coefficient indicates a lower speed of convergence of growth to its long-run equilibrium such that at13 \% of disequilibrium in the Real GDP is corrected within a quarter. 
Furthermore, the negative and significant coefficient is an indication of co-integrating relationship among RGDP and money supply.

\begin{tabular}{|c|c|c|}
\hline & Coefficient & Prob. \\
\hline D(RMS_gdp) & -223.15 & 0.009 \\
\hline D(RCPS_gdp) & 83.92 & 0.001 \\
\hline D(RBDL_gdp) & 184.9 & 0.018 \\
\hline D(IR) & 0.99 & 0.548 \\
\hline D(RGCF_gdp) & -57.07 & 0.023 \\
\hline D(RTT_gdp) & 0.60 & 0.933 \\
\hline ECM (-1) & -0.13 & -0.018 \\
\hline C & 274.02 & 0.000 \\
\hline Trend & 19.92 & 0.000 \\
\hline \multicolumn{2}{|c|}{$\begin{array}{c}\text { R-squared } \\
\text { Adjusted R-squared } \\
\text { 0.9981 }\end{array}$} \\
\hline
\end{tabular}

Table 3: Results of the Error Correction Model for Output

\section{Discussion of Findings}

This study was interested by the need to confirm the effect of money supply on economic growth in Rwanda. Using quarterly time series data spanning the period of 2000-2015, we examined the long and short run connection between money supply and economic growth in Rwanda. The stationarity test on the variables in the model showed that RGDP was stationary at I (0) while money supply was integrated at I(1). Therefore, all variables were entered in the model at their integration form in order to run the co-integration estimates. The result of the co-integration estimates in the study showed that money supply in this research explains negative long-run relationship on economic growth. This confirms with Gatawa (2016), as Abdulgafar and Olarinde (2017) findings among others.

The ECM was found to be negative and significant which shows the stability of the model. Additional, ECM revealed that $13 \%$ of disequilibrium inaccuracy is corrected within every quarter which representing a considerable speed of correction. The proof from our empirical study shows that the full model is stable within the period of study.

\section{Conclusions and Recommendations}

From our empirical analysis, the result supported for a significant negative influence between money supply and growth of economy(RGDP), the findings of this study emphasize the findings of some of the previous works that money supply does not play role in stimulate the economic growth.

We therefore recommend Rwandan policy makers ought not utilize money supply to stimulate economic growth. The policy makers need to look at other macroeconomic environment that could influence the growth of the Rwanda economy. Some of them include credit to private sector or bank deposit liability.

\section{References}

i. Abdulgafar and Olarinde (2017). Dynamic Impact of Money Supply on Economic Growth in South Africa

ii. Aslam et al (2011). An Econometric Analysis of the Impact of Money Supply on Sri Lankan Economy.

iii. Babatunde et al (2011). Study of Inflation, Money Supply and Economic Growth in Nigeria.

iv. Bednarik, R. (2010). Money Supply and real GDP: The case of the Czech Republic.

v. Chude et al. (2016). Impact of Broad Money Supply on Nigerian Economic Growth. IIARD International Journal of Banking and Finance Research.

vi. Ehigiamusoe, U. K. (2013). The Link between Money Market and Economic Growth in Nigeria: Vector Error Correction Model Approach. International Journal of Economics and Management Engineering.

vii. Esso (2010). Co-coordinating and causal connection between monetaryadvancement and financial development in ECOWAS nations.

viii. Gatawa et el 2016). Impact of Money Supply and Inflation on Economic Growth in Nigeria

ix. Hameed, I., and Amen, U. (2011). Impact of Monetary Policy on Gross Domestic Product (GDP).

x. Hussain et al. (2017). Empirical Analysis of the Relationship between Money Supply and Per Capita GDP Growth Rate in Bangladesh. Journal of Advances in Economics and Finance.

xi. Ihsan et el (2013). Impact of Money Supply on real growth domestic product of Pakistan.

xii. IMF (2018). Monetary Policy and Central Banking

xiii. MINECOFIN (2012). Rwanda National Savings Mobilization Strategy

xiv. Mohammad, S.D, Hussain, A. et al (2009). An Empirical Investigation between Money Supply and output in Pakistan.

xv. Ogunmuyiwa et al (2010). Effect of money supply and economic growth nexus in Nigeria.

xvi. Prasert Chaitip et al (2015). Money Supply Influencing on Economic Growth-wide Phenomena of AEC Open Region. Thailand

xvii. Robert.N and Nina (2015). The Impact of Money Supply on Economic Growth: Theory, Experience and Modelling, 
xviii. Saša O. et al. (2015). Causality relationship between financial Intermediation by banks and economic growth: Evidence from Serbia

xix. World Bank(2018). Rwanda Economic Update. Tackling Stunting: An Unfinished Agenda

xx. Zapodeanu et al (2010). Linking Money Supply with the Gross Domestic Product. Case study Romania. 